\title{
Environmental Upgrading in Pakistan's Sporting Goods Industry in Global Value Chains: A Question of Progress?
}

\author{
Amira Khattak ${ }^{1}$, Christina Stringer ${ }^{2}$
}

\begin{abstract}
The key objective of this paper is to examine factors which encourage or impede the environmental upgrading of Pakistani sporting goods firms in global value chains (GVCs); the sporting goods industry being one of Pakistan's main export sectors. Our research shows that buyer firms can be influential in the environmental upgrading of suppliers in GVCs due to their market power and resources. Supplier firms comply with environmental standards set by buyer firms to avoid being excluded from GVCs. However, not all GVCs provide conditions for environmental upgrading by supplier firms, since this depends very much on the type of network (governance mechanisms) in which the firms are embedded. In this paper, we explain how capable suppliers in relational networks were able to successfully embrace and implement environmental upgrading.
\end{abstract}

Keywords: Global value chains (GVCs), environmental upgrading, governance, sporting goods industry, Sialkot, Pakistan.

\section{Introduction}

In recent years, new trading and internationalisation patterns characterised by functionally integrated but globally dispersed industrial structures, termed as global value chains (GVCs), have emerged (Bair, 2009). A common feature of GVCs is that lead firms (buying firms in most cases) co-ordinate the activities of economic actors across the chain (upstream and downstream). Lead firms are also termed 'channel captains' because of the firms' power to influence the behaviour of other chain members (Roger \& Peterson, 2011). The power exercised by lead firms is conceptualised as governance mechanism in GVCs. While lead firms continuously seek cost reductions, quality, increased speed and conformance to code of conducts, at the same time they can transmit best practices and advice to participating firms (Humphrey, 2001), thus

1 Assistant Professor, Department of Marketing, College of Business Administration, Prince Sultan University, Saudi Arabia. Email: akhattak@psu.edu.sa

2 Associate Professor, The University of Auckland, New Zealand.Email: c.stringer@auckland.ac.nz

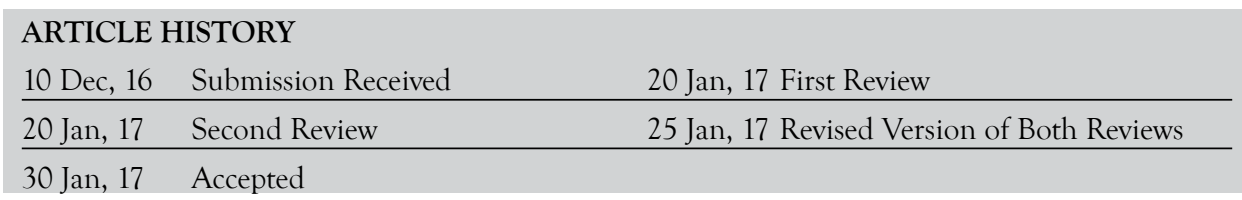


potentially stimulating learning and upgrading along the chain (Gibbon \& Ponte, 2005). As such GVCs have the potential to become important vehicles for international knowledge diffusion which in turn has created opportunities for supplier firms to benefit from upgrading opportunities (Ramirez \& Rainbird, 2010).

GVCs provide a stepping stone for firms, in particular suppliers in developing countries to integrate into the global economy (Gereffi \& Fernandez-Stark, 2011). Through their participation in GVCs, supplier firms can benefit from upgrading opportunities through learning and knowledge diffusion in GVCs. Importantly, supplier firms can identify those points where entry into the chain will give them higher returns on investments (Kaplinsky, 2000). The opportunity for supplier firms to switch from low to high value-added products-in short, economic upgrading-has been widely discussed in the GVC framework (Barrientos, Gereffi, \& Rossi, 2011; Cammett, 2006; Milberg \& Winkler, 2010), however recent contributions have highlighted concerns that the research on environmental dimensions of the globalisation of production and trade is still in its infancy (De Marchi, Di Maria, \& Micelli, 2013; De Marchi, Di Maria, \& Ponte, 2013; Goger, 2013; Khattak, Stringer, Benson-Rea, $\&$ Haworth, 2015). Lead firms can encourage suppliers to undertake environmental initiatives by implementing environmental requirements and standards, as well as by offering future contracts. As part of this process, lead firms can transmit knowledge to suppliers regarding emerging trends and policies in environmental standards. Nevertheless, lead firms can play a key role in implementing and enforcing environmental strategies, at least until formal institutions actively start setting and enforcing environmental standards. As mentioned by Pickles (2010) industrial structures and governance mechanisms can clearly affect the ability to embrace and maintain environmental management practices in GVCs. Hence, due to the exploratory nature of environmental upgrading research, we need more empirical studies to support the conceptualisation of the processes and outcomes of environmental upgrading in order to better arrive at practical solutions for businesses and policy makers. This paper aims to address that gap using the sporting goods industry (encompassing apparel, equipment and footwear) in Pakistan as a case study.

There are well defined reasons behind the selection of the sporting goods industry. Key reasons include the rapid growth of the industry globally. The industry is growing faster than overall gross domestic product (GDP) of fast-growing economies such as the Brazil, Russia, India and China (BRIC) countries and mature markets including Europe and the United States of America (USA) (ATKearney, 2011). Materials and processes used in manufacturing sporting goods can have potential environmental risks, for example, petroleum-based solvents used in athletic footwear production and other potentially damaging compounds, such as sulfur hexafluoride in air bladders for 
cushioning and impact shock absorption (Subic, Mouritz, \& Troynikov, 2009). Further, apparel manufacturing itself has several environmental consequences associated with it, for example, making synthetic fabrics, such as polyester, uses large amounts of crude oil and other materials that release volatile compounds (Binkley, 2010).

The sporting goods industry has been an integral part of Pakistan's economic development. The industry provides employment for between 300,000 to 350,000 skilled and unskilled workers and represents approximately 1.42 percent of the country's total export base (Afraz, Hussain, \& Khan, 2014). The sporting goods manufacturing industry is located in the town of Sialkot, in northeast Pakistan, and consists of approximately 390 firms out of which only a handful are large sized firms - the rest being small and medium-sized firms (SMEs) (Lund-Thomsen, 2013). Pakistan produces top end, high and medium quality hand-stitched footballs (soccer balls) (Lund-Thomsen, 2013). Pakistan supplier firms supply top global brands such as Adidas, Nike, Puma, Select, Litto, Wilsons Decathion. The sporting goods sector is forward looking, high enterprising and export oriented. While football manufacturing remains the foundation of the industry, product upgrading has occurred. Recently firms in Sialkot have started manufacturing other types of balls for example basket, sala, volley, hand and rugby balls. Further, firms have also moved into apparel, footwear, sports accessories, bags, sports equipment and gloves. The history of production of hand-stitched balls dates back to the late nineteenth century when Sialkot began to produce leather sports goods for the ruling British (Xue \& Chan, 2013). Seventy-one percent of all footballs imported into the USA in the mid-1990s were manufactured in Pakistan. Further, Pakistan is the European Union's (EU) main supplier of footballs (Siegmann, 2008). Football contributes the highest share (43\%) of the global sports market and is growing faster than tennis and golf after rugby (ATKearney, 2011). In the 1980s Sialkot gained international celebrity status when it produced the "Tango Ball" used at the Fédération Internationale de Football Association (FIFA) Football World Cup in 1982 which in turn led to the further growth of the football industry (Pakistan Today, 2014). Sialkot made "Brazuca" for FIFA Football World Cup matches in Brazil after a gap of 32 years.

Despite being a key sector there has been little uptake of environmental initiatives despite increasing concerns about environmental degradation in the industry, in particular the apparel and footwear sectors. Pakistani apparel firms lag behind in terms of engaging in environmental upgrading particularly when compared with other producers in South Asia. For example, in 2014, there were 11 apparel firms in Bangladesh and 5 apparel firms in Sri Lanka with Leadership in Energy and Environmental Design (LEED) certification (The Green Building Information Gate, 2014). In 
Pakistan, only two firms had LEED certification. LEED is an environmental global standard and many countries have adopted LEED as the main green building standard globally (Holcim, 2009). LEED certification addresses not only carbon emission but also other aspects of environmental sustainability such as energy, water and waste management (Holcim, 2009). Instead the International Standards Organization (ISO) 14001 certification, while in itself not strongly supported internationally, is the preferred environmental standard in Pakistan (United Nations Industrial Development Organization (UNIDO), 2007). The ISO 14001 standard describes the organisational structure, responsibilities, practices, procedures, processes and resources for maintaining a firm's environmental policy (Marimon-Viadiu, Casadesus-Fa, \& Heras-Saizarbitoria, 2006). ISO is the largest developer of sustainability standards in the world and thus ISO standards are widely accepted (David, 2011).

Despite the low uptake to-date of firms engaging and benefiting from environmental upgrading, the industry and industry associations in Sialkot are very active and have a history of undertaking successful collaboration initiatives with the Pakistani government as well as non-governmental local and global actors in regards to social upgrading (Giuliani, 2016). For example, the Sialkot Chamber of Commerce and Industry (SCCI) financed part of the International Labour Organization's (ILO) programme to eliminate child labour and in addition played a key role in developing a child labour monitoring system subject to the ILO for independent and external verification (Lund-Thomsen \& Nadvi, 2010). Until now the studies on collaboration between economic and non-economic actors have focused on social initiatives or in other words social upgrading in GVCs (see Lund-Thomsen, Lindgreen \& Vanhamme, 2016). More studies are needed to address the deficit in studies on environmental initiatives in GVCs. Thus, the findings of this study can benefit the sporting goods industry in terms of understanding the importance of environmental processes for future research agendas and business plans.

The main research objective is to assess the impact of governance patterns on environmental upgrading of Pakistani supplier (sporting goods) firms embedded in GVCs, and the research question asks: What factors enable or impede the environmental upgrading of sporting goods firms within GVC? To achieve this objective, we investigated the context of Pakistan, with the sporting goods industry of Sialkot selected as a case study. The paper proceeds as follows. First, we briefly review the GVC literature on governance structures. Recent research reveals that environmental upgrading is highly dependent on the types of networks (GVCs) or position of the lead firm versus supplier firms (Achabou, Dekhili, \& Hamdoun, 2017; Khattak \& Stringer, 2016). Therefore, in order to arrive at a systematic analysis of the environ- 
mental upgrading of firms, it is critical to analyse the governance mechanisms of the networks in which the firms are embedded. We then set out the research method in section 3 . In section 4 , the findings are presented before concluding with a discussion and implications of the research.

\section{Environmental Upgrading in Global Value Chains}

\subsection{Governance}

The variations among GVCs are due to differences in their governance structures (Bair, 2008). Governance refers to organisational processes through which lead firms coordinate the economic actors of the GVCs; and decide about the value addition and value extraction across the chain (Palpacuer, Gibbon, \& Thomsen, 2005). In his initial conceptualisation of GVCs, Gereffi (1994) identified two types of chains: producer-driven chains led by manufacturers retaining control of capital-intensive operations and buyer-driven chains led by lead firms which set up decentralized production networks and outsource production to internally competing networks. However, this original distinction was thought to overlook different and, perhaps, more complex governance networks; Gereffi, Humphrey, and Sturgeon (2005) subsequently identified five possible types of governance structures (discussed next). These were based on three constructs: the nature of transactions in terms of complexity; the extent to which the information can be codified and efficiently transferred; and the capabilities in the suppliers (Gereffi et al., 2005). Capability of suppliers refers to their ability to meet all the requirements of a transaction including specifications about quality, timely delivery as well as environmental and safety standards (Frederick \& Gereffi, 2009). In situations where the capabilities of suppliers are low, buyers may be forced to establish their own production facilities.

The five types of governance structures (market, modular, relational, captive and hierarchical) result from varying degrees of coordination based on the above mentioned variables (Gereffi et al., 2005). Suppliers with higher capabilities will make products in accordance with the customer's specifications. In relational networks, tacit information is exchanged between buyers and competent suppliers. Tacit knowledge refers to knowledge that is hard to codify and communicate and therefore it is acquired through observation, imitation and practice. In essence, the knowledge can be freely and easily used by its owners but cannot be easily expressed and communicated to others (Giuliani, Pietrobelli, \& Rabellotti, 2005). As the information is not easily codified, frequent interaction between lead firms and suppliers is required and thus relational networks are characterized by mutual dependency (Frederick \& Gereffi, 2009). Captive networks comprise less competent suppliers and thus detailed 
information regarding product and process is provided to them by lead firms which take an active role in monitoring and controlling suppliers. Lastly, hierarchical networks are characterized by lead firms which have established vertical linkages due to the complexity of transactions coupled with the low capabilities of the supply base (Sturgeon, 2009). The governance construct in GVC matters because access to some markets is only possible through lead firms. Governance is particularly important for the generation, transfer and diffusion of knowledge leading to innovation (Humphrey \& Schmitz, 2002) and identifying relationships characterized by a different level of involvement of suppliers in knowledge intensive activities or innovation (Saliola \& Zanfei, 2009).

In addition to governance initially being conceptualised as driving (buyer- and producer-driven chains), and later as co-ordination (five types of governance structures), more recently scholars have identified that governance can also be viewed through the lens of normalization (Gibbon \& Ponte, 2008; Ponte, Gibbon, \& Vestergaard, 2011). The term 'normalizing' mean "turning a given practice or quality into a standard or norm" (Larsen, 2014, p. 5). Simple compliance with social and environmental standards and obtaining certifications in this regard has become a norm in countries where formal rules and regulations do not exist. Firms adhere to social and environmental standards to avoid exclusion from GVCs, which provide firms with access to international lucrative markets. Compliance with these conventions and standards is a sine qua non for entry, for example, into apparel-based GVCs (Nadvi, 2008).

\subsection{Environmental Upgrading}

The most influential contributions to GVC studies have analysed and interpreted the concept of economic upgrading (product, process, functional and industry upgrading) and the extent to which different governance patterns foster or hinder economic upgrading in clusters or industries (Barrientos et al., 2011; Morrison, Pietrobelli, \& Rabellotti, 2008). Recent debates have highlighted concerns that the environmental dimension of the globalization of production are still in its infancy (Gereffi \& Fernandez-Stark, 2011; Khattak et al., 2015). Whilst a well-defined construct of 'environmental upgrading' did not exist in the GVC literature until very recently. One definition proposed was that "environmental upgrading is a way of reducing the 'environmental impact' along the value chain" (Duke-VIU International Summer Research Workshop, 2010). 'Environmental impact' refers to harmful effects on the environment, for example, carbon emission, depletion of natural resources, water and energy consumption and also after-use effects (waste, pollution and energy consumption). Hence, it covers three areas of any typical GVC, namely inputs, processes and outputs. Empirical definition of environmental upgrading is it "occurs when a 
firm, within a particular GVC, improves its environmental performance through changes in technological, social and organizational processes and by extension avoids or reduces its overall environmental impacts" (Khattak et al., 2015, p. 331). A limited number of research has been conducted so far and all are exploratory in nature with the aim to understand the construct of environmental upgrading along with its processes and core dimensions in GVCs (see De Marchi, Di Maria, \& Micelli, 2013; De Marchi, Di Maria, \& Ponte, 2013; Goger, 2013; Khattak \& Stringer, 2016; Khattak et al., 2015; Poulsen, Ponte, \& Lister, 2016). All these researchers emphasize the role of lead firms in environmental upgrading in GVCs, which supports our view that governance mechanisms are crucial factors influencing upgrading. One of the main contentions of all these studies is that environmental upgrading of any economic actor in GVCs takes place because of interaction of lead firms with these firms. Through regular interactions knowledge is created and transferred across the GVCs resulting in environmental upgrading.

Further, the competitiveness, performance and strategies of individual firms are also affected by the dynamics (institutional networks) of GVCs in which they are embedded. For example, after the phasing out of quantitative restrictions in the global apparel industry, lead firms consolidated their supplier's base (Appelbaum, 2008) which resulted in the emergence of limited but capable core suppliers (Palpacuer et al., 2005). Moreover, the pressure exerted by media and non-governmental actors on lead firms, resulted in the compliance based model forcing many lead firms to develop codes of conduct that prescribe the conditions under which products should be produced in developing countries (Lund-Thomsen \& Lindgreen, 2014). Hence a typical supplier firm is embedded in a wider institutional network including local, international and regional networks. Here it is worth mentioning that lead firms encourage their suppliers to adopt environmental friendly management practices due to possible future environmental rules and regulations in their countries (Khattak et al., 2015).

\section{Research Design}

The key philosophical assumption of this research is that "reality is constructed by individuals interacting with their social worlds" (Merriam, 1998, p. 6) and there are multiple constructions and interpretations of reality (Merriam, 2002). These philosophical assumptions pertain to interpretive and the qualitative paradigm (Collis \& Hussey, 2003; Creswell, 1994). To understand meaning constructed by managers, it is critical to talk and interview the managers to advance knowledge (Birkinshaw, 2004), understand the phenomenon in depth and contribute to theory. Moreover, the nature of environmental upgrading research being in exploration and refinement stages, necessitated qualitative research oriented towards exploration, discovery and 
inductive logic (Patton, 1990).

The environmental upgrading of suppliers is a fairly recent practice and not widespread. In order to understand how these processes and interactions are embedded in GVCs, in-depth semi-structured interviews were undertaken (Birkinshaw, 2004). The main research strategy adopted was a case study approach, as such an approach has "become one of the most common ways to do qualitative inquiry" (Stake, 2000, p. 435) and a frequently used approach in business and management (Ghauri, 2004). Further "case studies bring a deeper understanding of the process of upgrading, the role of each of the key actors and the obstacles that upgrading firms face in GVCs" (Milberg \& Winkler, 2011, p. 345). The case study approach used was an instrumental and collective case study (Stake, 1995, 2000), where one or more cases are studied to provide insight into an issue and optimise understanding of the case rather than generalisations beyond (Stake, 2003).

The sporting goods sector traditionally operates as a buyer-driven chain wherein buyer-firms with their market and commercializing power drive the chain in terms of value addition and extraction. Captive and relational networks are prevalent in the industry. The large firms are mostly in relational networks whereas SMEs are in captive networks as their capabilities make them a preferred choice for lead firms to form captive networks with. In 2014, the first author visited a number of organisations related to the sporting goods industry in Sialkot, including the SCCI, the Small and Medium Enterprises Development Authority (SMEDA), the Pakistan Sports Goods Manufacturers and Exporters Association (PSGMEA) and the Pakistan Readymade Garments Manufacturers and Exporters Association (PREGMA). Interviews were conducted with personnel in these organisations in order to obtain insights into the industry and in particular information on environmentally upgraded firms. ISO 14001 accredited firms were identified by the interviewees as potential firms to interview, as noted earlier, ISO 14001 is the highest environmental standard implemented in this sector. To identify accredited firms, the ISO office in Islamabad was contacted. There are, however, only a few firms accredited with ISO 14001 in the Sialkot sporting goods industry. Significantly, not one firm in the industry had been awarded LEED certification. This information was validated through information contained on the United States Green Building Council (USGBC) website listing LEED certified firms globally. An earlier study conducted by UNIDO (2007) in Pakistan also found that ISO 14001 was considered an emerging trend by firms in the sportswear industry of Sialkot.

Since qualitative inquiry seeks to understand the meaning of a phenomenon from the perspectives of participants, it is important to select a sample from which the most can be learnt (Merriam, 2002). Cases in this research were selected using 
a non-probability sampling method called purposive sampling. Purposive sampling is based on the assumption that "one wants to discover, understand, gain in-sight, therefore one needs to select a sample from which one can learn more" (Merriam, 1988 , p. 48) or, in other words, information rich cases from which a great deal about issues of central importance to the purpose of the research can be learnt (Patton, 1990). Five firms with environmental interests were sampled from recommendations of the above-mentioned organisations as well as from information obtained on ISO 14001 certified firms in the area. Three firms were large (more than 250 employees and with an annual turnover of more than Rs.400 million) and two were SMEs (between 20-250 employees and an annual turnover of between Rs.75-400 million) (State Bank of Pakistan, 2013). Table 1 provides an overview of the firms. Three types of firms-large, medium and small-were selected for the purpose of comparison. Size relates critically to the way in which firms are embedded in the institutional framework of the political economy and large firms respond differently to institutional change (Bluhm \& Schmidt, 2008). Furthermore, reflecting the GVC framework, firms in the study were selected on the basis of governance structures as well. Small firms in developing countries are in captive networks most of the times. Medium sized firms are in captive and relational networks, whereas large firms are in relational networks and few are moving towards modular form of networks (Khattak, 2013). Hence, selection of firms on the basis of size was sound and logical methodologically. Importantly the three large firms selected were actively involved in environmental upgrading and were in relational networks as core suppliers to brand-named lead firms. By relational network we refer to the complexity of transactions being high, the ability to codify information related to the design of sporting goods low and suppliers' capabilities high. Here it is worth mentioning that initially it was decided that interviews will be conducted with compliant (ISO 14001 certified) firms and non-compliant firms. However, non-compliant firms were withdrawn after two interviews with non-compliant firms because the managers and owners did not have any idea about environmental management practices and processes.

Semi-structured interviews were undertaken in 2014 with the most knowledgeable and relevant member(s) of the firms (Van Maanen, 1979). Interviews were undertaken with more than one interviewee in two of the large firms (Firm 1 and Firm 3). In Firm 1, one interview was conducted with the owner of the firm who was also the General Manager (GM) and a second interview with the Director, Operation Manager. In Firm 2, an interview was conducted with the GM. In the third firm, two interviews were conducted; one with the export/marketing cum production Manager and the second with the owner/GM. Interviews were conducted with the production cum marketing managers in the SMEs. Each interview lasted approximately one to two hours. The interviews were conducted in Urdu (national language of Pakistan), 
translated to English and retranslated back to Urdu to ensure that the meaning was not been lost in the translation process. In addition to interview data, secondary data were collected from reports, newsletters, and websites.

Data analysis was an inductive process. The first stage involved comparison of one unit of data with other units of data to look for common patterns across the data. Those patterns were given names (codes) for categorisation purposes (Gibbs, 2007). Coding helps in breaking down, conceptualising, categorising and presenting data in an understandable manner (Ghauri, 2004). Hence, the data were arranged into conceptual categories under theory-driven or a priori codes and data-driven or emergent codes (Boyatzis, 1998). Theory-driven codes are also called 'concept-driven' codes based on a list of key thematic ideas derived from the chosen theoretical framework (Gibbs, 2007).

The second stage involved a process called axial coding (Strauss \& Corbin, 1990), in which codes were refined, similar conceptual categories were merged and an attempt was made to arrive at 'core categories' or 'central categories' that tie all categories in the theory together into a story (Gibbs, 2007). Due to the reason that the environmental upgrading is a new practice, limited emergent codes were derived from the data. The third stage involved establishing and explaining relationships between codes, and the final stage involved 'pattern matching' (Ghauri, 2004, p. 118) in which comparisons between empirically based patterns and prior theory were made and empirical findings were linked back to the wider theoretical literatures. In pattern matching, the researcher compares an empirically based pattern of events with several alternatives or predicted alternatives (Pauwels \& Matthyssens, 2004). The next section discusses our findings.

\section{Environmental Upgrading: Requirements, Drivers, and Processes}

\subsection{Environmental Upgrading Requirements}

Findings suggest that international buying firms' requirement in terms of environmental compliance is ISO 14001. As mentioned by Firm 1 "nowadays ISO 14001 is very important because it is in demand by international top brands". Despite this requirement, not all buying firms require supplier firms to be certified. There was a difference between branded and non-branded lead firms, such as small importer distributors and wholesalers, in terms of encouragement or pressure for supplier firms to upgrade. Firm 3 commented: "Suppliers manufacturing for non-branded companies are least concerned [about environmental upgrading]. Large firms [branded] are under pressure because they are more exposed to media and others". 
Table 1: Details of Cases

\begin{tabular}{|c|c|c|c|c|c|}
\hline Cases & Firm Size & Governance & $\begin{array}{l}\text { Number of em- } \\
\text { ployees in } 2016\end{array}$ & Buyers & Product Lines \\
\hline Firm 1 & Large & Relational & 2,300 & $\begin{array}{c}\text { Nike } \\
\text { Umbro Sports } \\
\text { Jako Sports } \\
\end{array}$ & $\begin{array}{c}\text { Footballs, apparel } \\
\text { and footwear }\end{array}$ \\
\hline Firm 2 & Large & Relational & 2,100 & $\begin{array}{c}\text { Adidas } \\
\text { Lotto } \\
\text { Diadora } \\
\text { Admiral } \\
\text { Champion } \\
\text { Sports }\end{array}$ & $\begin{array}{l}\text { Balls (foot, basket, } \\
\text { sala, volley, hand), } \\
\text { goal keeper gloves, } \\
\text { accessories, football } \\
\text { shoes and bags }\end{array}$ \\
\hline Firm 3 & Large & Relational & 700 & $\begin{array}{c}\text { Adidas } \\
\text { Molten } \\
\text { Diadora } \\
\text { Tachikara } \\
\text { Webb Ellis } \\
\text { Spalding } \\
\text { Spartan } \\
\text { Kappa }\end{array}$ & $\begin{array}{l}\text { Balls (rugby, foot, } \\
\text { basket and vol- } \\
\text { ley), apparel and } \\
\text { footwear, bags and } \\
\text { sports accessories }\end{array}$ \\
\hline Firm 4 & SME & Captive & 250 & $\begin{array}{l}\text { Unbranded } \\
\text { importers, re- } \\
\text { tailersand small } \\
\text { branded buyers }\end{array}$ & $\begin{array}{l}\text { Balls, apparel, box- } \\
\text { ing equipment and } \\
\text { goal keeping gloves }\end{array}$ \\
\hline Firm 5 & SME & Captive & 250 & $\begin{array}{l}\text { Unbranded im- } \\
\text { porters, retailers } \\
\text { and small brand- } \\
\text { ed buyers }\end{array}$ & $\begin{array}{l}\text { Balls (foot, basket, } \\
\text { rugby, volley), goal } \\
\text { keeping gloves, ap- } \\
\text { parel and accessories }\end{array}$ \\
\hline
\end{tabular}

Source: Authors

These findings were confirmed by a UNIDO study in Pakistan which found that in terms of environmental compliance, there are no specific requirements by international buyers except for two requirements related to raw materials (UNIDO, 2007). The first requirement is that raw materials should be azo and heavy metal (lead, cadmium, and chromium) free. Further, these requirements are for promotional balls and not professional balls (UNIDO, 2007). Azo dyes are considered a serious chemical hazard by the International Association of Research and Testing in Textile Ecology, as substandard dyes and chemicals used to make various colours of fabrics and goods may be environmentally dangerous (Khan, 1998). The second requirement is that the raw material should be Penta Chloro Phenol (PCP) free. Buyers typically specify the source of dyes and chemicals and as such there is no specific certification 
pertaining to compliance with these two requirements. Tests for Azo compounds and heavy metals are conducted by accredited third party organisations.

The UNIDO (2007) study found that the majority of Pakistani firms in the sporting goods industry were interested in being certified by the Conformite' Europe'en (CE) Mark but did not apply for certification because the buyers did not require CE Mark. This is despite, the CE Mark being a requirement for the majority of products entering the EU market as a confirmation that the product meets EU health, safety and environmental standards. To-date environmental certification is not a major trend prevailing in the sporting goods industry, instead social certifications were prevalent in the majority of firms in the industry for example Social Accountability (SA) 8000 and the Worldwide Responsible Accredited Production (WRAP). "SA8000 covers human right issues including child labour, forced labour, discrimination, health \& safety, freedom of association \& right to collective bargaining, disciplinary practices, working hours and remuneration" (Stigzelius \& Mark-Herbert, 2009, p. 49). Similarly, WRAP Principles include common standards for child and forced labour (O'Rourke, 2003).

Until now, as mentioned earlier in the introduction section, buyers are pushing suppliers more along social dimensions and to lesser extent environmental dimension particularly in the sporting goods industry. Importantly all the firms interviewed believed that standards, including ISO 14001, were becoming core parameters and pre-requisites to enter international markets.

\subsection{Environmental Upgrading Drivers}

There were two keys drivers of environmental upgrading in the sporting goods industry in Sialkot. The first driver was the lead firms and the second was the suppliers themselves. The role of lead firms (buyers) is critical in the environmental upgrading strategies of the three large supplier firms. The buyers advised their supplier firms to engage in upgrading. One interviewee (Firm 1) reflected on the importance of the buyer firms as an information source:

Awareness of social and environmental concerns and information comes from our customers [buyers/brand marketers] who cannot afford social and environmental violations. They push us and train us.

Brand marketers, for example Adidas and Nike, often decide which core suppliers (first tier) they will encourage to upgrade. Core suppliers are expected to play a wide variety of functions, for example, holding stock (resulting in decreased inventory levels for the lead firms), new product development, purchasing raw materials and analysis of sales data and predication of demand (Palpacuer et al., 2005). Therefore, it can be assumed that the circumstances are more favourable for the environmental upgrading 
of core suppliers in relational networks, involving complex transactions, information related to transactions are not easily codified and the capabilities of the supplier firms themselves is high. Further, the role of buyers is crucial in sharing information about new trends in the global apparel industry, for example, environmental practices and possible rules and regulations pertaining to environment in the major apparel importing countries. These processes of knowledge sharing are possible due to direct and frequent interactions between buyers and suppliers. This relationship could be viewed as collaboration between buyer and suppliers with the primary requirement being common or complementary goals and communication (Martin \& Schouten, 2015). It must be noted here that the large firms in the sporting goods industry of Sialkot were serious in implementation of environmental management practices first due to the reason that it was preferred by their buyers with whom they were in strategic relationship and secondly after realisation of huge cost savings and economic benefits. Economic benefits were realised after firms implemented environmental management practices.

A second driver of environmental upgrading were the SME supplier firms themselves perceiving that they could potentially have better access to international markets if they were internationally certified. The two SME firms (Firm 4 and 5) were both operating in captive networks and had applied for ISO 14001certification on their own instigation. "Without certification, we cannot receive orders because customers always ask what types of certification we have" (Firm 4). Although environmental certifications were not one of the main requirements by the buyers as mentioned in the previous section, however, SME firms perceived that holding environmental certification will make them eligible suppliers by the foreign customers. Nevertheless, SME supplier firms were not enthusiastic about applying for ISO 14001 certification, though those firms held ISO 14001 certifications. One of the reasons behind non-serious attitude towards implementation of environmental management practices was inconsistent (irregular) orders as mentioned by SMEs. This interaction with customers propelled the firms to apply for ISO 14001certification in order to access international markets only. Unfortunately, not all supplier firms in Sialkot are as proactive; with many relying on signals from buyers and many firms even did not have idea about environmental upgrading or environmental-friendly practices.

\subsection{Environmental Upgrading Processes}

According to Khattak et al. (2015) there are four major areas in a typical apparel sector where environmental initiatives or improvements can take place: energy, water, waste management and carbon emissions. In the context of this study all the interviewees mentioned that the environmental impact of the manufacturing of 
sporting goods, in particular football was not detrimental. In fact, most of firms were manufacturing footballs where "water consumption is negligible" (Firm 2) and less waste created: "major waste is recycled and bought by raw material suppliers" (Firm 3). Instead carbon emission and energy consumption were the core areas of environmental concern. Specific to the sporting goods industry, the interviewees identified other areas of environmental concern, for example, the chemicals used and fumes generated during the printing of footballs. In response, one firm (Firm 1) had replaced petroleum-based chemicals with water-based chemicals and installed air suction ducts to evacuate Volatile Organic Compounds (VOC) on one hand and to tackle the carbon emissions issue on the other in order to meet ISO 14001 requirements.

\section{Discussion and Implications}

Our empirical findings identified that the five firms interviewed from the Sialkot sporting goods industry were embedded in different GVC networks and that their environmental upgrading depended very much on the type of governance mechanism in which they are embedded. The three large firms were in relational networks and were able to successfully embrace and implement environmental upgrading initiatives. Importantly, they were encouraged to do so by the buyer firms. Thus, core suppliers in relational networks have better opportunities - depending, of course, on the lead firm - to successfully embrace and implement environmental upgrading. The other two firms, both SMEs, initiated their own upgrading in order to develop their capabilities and gain further access to international markets. They were not in relationships with key buyer firms and instead were in a captive network with non-branded firms. Our findings are in line with other studies (though in its infancy) which emphasize the role of buyers in environmental upgrading through interactions and knowledge transfer (see Achabou et al., 2017; Khattak \& Stringer, 2016; Poulsen et al., 2016). Our findings also suggest that size of any typical firm was very important in determining the relationship of suppliers and buyers and ultimately resultant governance mode. There are substantial costs related to environmental upgrading, which can be best viewed in relation to the size and financial viability (Kaplinsky, 2010) of firms. A new dimension of the study, which is different from previous research, is SMEs applying for certification on their own, however, such firms were not able to avail the same benefits as were availed by firms pushed by lead firms. Moreover, SMEs were not following environmental management practices in its true spirits which could be as a result of unable to avail benefits which were expected when applying and incurring costs of ISO 14001 certification. Supplier firms in GVCs comply with environmental standards set by buyer firms to avoid being excluded from GVCs. Lead firms will remain the core institutional force of implementation of environmental and green strategies, at least until other institutions or formal regulations actively start setting 
and enforcing environmental standards.

Further, compliance with international standards typically provides a competitive edge for firms over others in an industry (Kaplinksy, 2010). There can be two major competitive effects related to environmental competencies: impeding and facilitating (Jeppesen \& Hansen, 2004). A supplier firm's competencies can impede collaboration with a lead firm because their (the supplier firm's) capabilities may be scarce and difficult to replicate: "it may be impossible for lead firms to internalize functions or find substitute suppliers in time to compete effectively" (Sturgeon, 2009, p. 121). Since buyers and suppliers depend on each other's resources and knowledge, they coordinate so that their respective goals are achieved (Wong \& Johansen, 2008). Hence, lead firms are more interested in environmental upgrading of suppliers with capabilities, because they are dependent on them and it is very costly to switch capable suppliers. On the other hand, environmental competencies (such as those firms which became certified on their own) can enhance the competitiveness of such firms because lead firms collaborate with firms having certifications (Jeppesen $\&$ Hansen, 2004). Lead firms may enter into a strategic relationship with environmental upgraded firms. For example, in the global apparel industry, compliance systems such as labor, social, and environmental standards have been developed due to pressure exerted by consumer organisations and non-governmental actors. Subsequently such compliance systems are used by lead firms to distinguish among and select suppliers (Messner, 2002). The compliance with standards aspects of findings aligns with the normalization perspective of governance mechanisms in GVCs (Gibbon \& Ponte, 2008; Ponte \& Gibbon, 2005; Ponte et al., 2011). Compliance with social and environmental standards and obtaining certifications in this regard is becoming a norm in countries where formal rules and regulations do not exist. Firms adhere to social and environmental standards to avoid exclusion from GVCs, which provide firms with access to international lucrative markets. This has important implications for the future of the Pakistani sporting goods industry.

Currently, while there are no strict environmental requirements imposed on the sporting goods industry internationally, and as mentioned earlier supplier firms elsewhere in South Asia are actively engaging in environmental upgrading thus achieving a first-mover advantage. Thus, Pakistani firms are lagging behind both in terms of environmental management practices and global certificate accreditation. Hence, they are likely to face increased competition if compliance with international environmental standards becomes a pre-requisite for entry into GVCs. Indeed, Pakistan's low uptake of environmental standards is puzzling. The sporting goods firms need to rethink their business models in environmental terms in order to reap the benefits of 'going green'. Businesses often perceive sustainability as a burden on bottom lines; 
however in actuality going green may lower business costs (Nidumolu, Prahalad, \& Rangaswami, 2009). Pakistani firms not in a core relationship with buyer firms which are encouraging them to upgrade, should, therefore, initiate environmental upgrading and obtain international certification, in order to become attractive for other buyers in GVCs. Participation in GVCs does not automatically provide conditions for environmental upgrading.

While lead firms have the capability to set and/or enforce environmental parameters that are not set and/or enforced by institutional actors, nevertheless, the role of state and non-state actors particularly in developing countries, cannot be under-estimated. The Pakistan government and industry associations which have in the past successfully collaborated in terms of social upgrading initiatives should look at possible collaboration strategies in regards to environmental initiatives. A more proactive approach on part of both industry association and the government is recommended. As mentioned earlier that until now buyers are pushing suppliers more along social dimensions and to lesser extent in terms of environmental standards in particular in the sporting goods industry.

It goes without saying that a key limitation of our study is that it is based only on a small sample of firms. The sample size is due to the low uptake of environmental standards in Pakistan. More broadly, there is much research to be done on how drivers behind firms in other industries engage in environmental upgrading. Further, we suggest that future research could test our findings in other industries where there are larger sample of firms. Here it is worth mentioning that as poverty, pollution, deforestation and other environmental problems have proved to be strictly correlated in developing countries (Dasgupta, Deichmann, Meisner, \& Wheeler, 2005). Future researchers could study the relationship between environmental and social upgrading from two perspectives, i.e. as Khattak and Stringer (2016) state:

Firstly, from employees' perspectives; emphasizing employee's rewards (entitlements) through involvement in the environmental upgrading processes and improved health and safety conditions at the workplace, for example. Secondly, from a community (regional) perspective, where natural resources are not depleted but protected, and which hence provide sustainable sources of income and places to live to the larger community. (p. 553-554)

\section{References}

Achabou, M. A., Dekhili, S., \& Hamdoun, M. (2017). Environmental upgrading of developing country firms in global value chains. Business Strategy and the Environment, 26(2), 224-238

Afraz, N., Hussain, S. T., \& Khan, U. (2014). Barriers to growth of small firms in Pakistan: A qualitative 
assessment of selected light engineering industries. Lahore Journal of Economics, 19(Special Edition), 135-176.

Appelbaum, R. P. (2008). Giant transnational contractors in East Asia: Emergent trends in global supply chains. Competition $\mathcal{E}$ Change, 12(1), 69-87.

ATKearney. (2011). The sports market: Major trends and challenges in an industry. Retrieved June 28, 2015, from https://www.atkearney.com/documents/10192/6f46b880-f8d1-4909-9960cc605bb1ff34

Bair, J. (2008). Analysing global economic organization: Embedded networks and global chains compared. Economy E Society, 37(3), 339-364.

Bair, J. (2009). Frontiers of commodity chain research. Stanford, CA: Stanford University Press.

Barrientos, S., Gereffi, G., \& Rossi, A. (2011). Economic and social upgrading in global production networks: A new paradigm for a changing world. International Labour Review, 150(3-4), 319-340.

Binkley, C. (2010). How green is my sneaker? The Wall Street Journal. Retrieved July 21, 2011, from http:// online.wsj.com/article/SB10001424052748703724104575379621448311224.html

Birkinshaw, J. (2004). Publishing qualitative research in international business. In R. Marschan-Piekkari \& C. Welch (Eds.), Handbook of qualitative research methods for international business. Cheltenham, UK: Edward Elgar.

Bluhm, K., \& Schmidt, R. (2008). Change in SMEs: Towards a new European capitalism? Basingstoke, UK: Palgrave Macmillan

Boyatzis, R. E. (1998). Transforming qualitative information: Thematic analysis and code development. London, UK: Sage.

Cammett, M. (2006). Development and the changing dynamics of global production: Global value chains and local clusters in apparel manufacturing. Competition $\mathcal{E}$ Change, 10(1), 23-48.

Collis, J., \& Hussey, R. (2003). Business research: A practical guide for undergraduatesand postgraduate students. New York, NY: Palgrave Macmillan.

Creswell, J. W. (1994). Research design: Qualitative and quantitative approaches. London, UK: Sage.

Dasgupta, S., Deichmann, U., Meisner, C., \& Wheeler, D. (2005). Where is the poverty-environment nexus? Evidence from Cambodia, Lao PDR, and Vietnam. World Development, 33(4), 617-638.

David, F. R. (2011). Strategic management: Concepts and cases (13 ed.). New Delhi: PHI Learning Private Limited.

De Marchi, V., Di Maria, E., \& Micelli, S. (2013). Environmental strategies, upgrading and competitive advantage in global value chains. Business Strategy and the Environment, 22(1), 62-72.

De Marchi, V., Di Maria, E., \& Ponte, S. (2013). The greening of global value chains: Insights from the 
furniture industry. Competition $\mathscr{E}$ Change, 17(4), 299-318.

Duke-VIU International Summer Research Workshop. (2010). Retrieved June 21, 2011, from http:// www.univiu.org/other-programs/ongoing-programs/duke-viu-workshop

Frederick, S., \& Gereffi, G. (2009). Value chain governance.Retrieved October 20, 2011, from http:// microlinks.kdid.org/library/value-chain-governance-briefing-paper.

Gereffi, G. (1994). The organization of buyer-driven global commodity chains: How U.S. retailers shape overseas production networks. In G. Gereffi, M. Korzeniewicz \& R. P. Korzeniewicz (Eds.), Commodity chains and global capitalism. London, UK: Praeger.

Gereffi, G., \& Fernandez-Stark, K. (2011). Global value chain analysis: a primer. Center on Globalization, Governance \& Competitiveness (CGGC), Duke University, North Carolina, USA.

Gereffi, G., Humphrey, J., \& Sturgeon, T. J. (2005). The governance of global value chains. Review of International Political Economy, 12(1), 78-104.

Ghauri, P. (2004). Designing and conducting case studies in international business research. In R. M. Piekkari \& C. Welch (Eds.), Handbook of qualitative research methods for international business students. Cheltenham, UK: Edward Elgar.

Gibbon, P., \& Ponte, S. (2005). Trading down: Africa, value chains, and the global economy. Philadelphia, PA: Temple University Press.

Gibbon, P., \& Ponte, S. (2008). Global value chains: From governance to governmentality? Economy $\mathcal{E}$ Society, 37(3), 365-392.

Gibbs, G. (2007). Analyzing qualitative data. London, UK: Sage

Giuliani, E. (2016). Human rights and corporate social responsibility in developing countries' industrial clusters. Journal of Business Ethics, 133(1), 39-54.

Giuliani, E., Pietrobelli, C., \& Rabellotti, R. (2005). Upgrading in global value chains: Lessons from Latin American clusters. World Development, 33(4), 549-573

Goger, A. (2013). The making of a 'business case' for environmental upgrading: Sri Lanka's eco-factories. Geoforum, 47, 73-83.

Holcim. (2009). MAS intimates thurulie: Clothing factory in Sri Lanka. Zurich, Switzerland: Holcim Foundation for Sustainable Construction.

Humphrey, J. (2001). Governance in global value chains. IDS bulletin, 32(3), 19-29.

Humphrey, J., \& Schmitz, H. (2002). How does insertion in global value chains affect upgrading in industrial clusters? Regional Studies: The Journal of the Regional Studies Association, 36, 1017-1027.

Jeppesen, S., \& Hansen, M. W. (2004). Environmental upgrading of Third World enterprises through linkages to transnational corporations. Theoretical perspectives and preliminary evidence. Business 
Strategy and the Environment, 13(4), 261-274.

Kaplinsky, R. (2000). Globalisation and unequalisation: What can be learned from value chain analysis?. Journal of development studies, 37(2), 117-146.

Kaplinsky, R. (2010). The role of standards in global value chains. World Bank Policy Research Working Paper. Washington, DC: World Bank.

Khan, S. M. (1998). Pakistan and International Textile and Clothing Trade Regime. M.Phil Dissertation, The University of Salford, Salford.

Khattak, A. (2013). A comparative analysis of South Asian apparel firms in global value chains: governance, institutions and upgrading (Doctoral thesis, The University Auckland, Auckland, New Zealand). Retrieved November 10, 2016, from https://researchspace.auckland.ac.nz/handle/2292/20053

Khattak, A., \& Stringer, C. (2016). The role of suppliers in the greening of GVCs: Evidence from the Sri Lankan apparel industry. In M. Mustafa Erdoğdu, T. Arun \& I. H. Ahmad (Eds.), Handbook of research on green economic development initiatives and strategies. Hershey: IGI Global.

Khattak, A., Stringer, C., Benson-Rea, M., \& Haworth, N. (2015). Environmental upgrading of apparel firms in global value chains: Evidence from Sri Lanka. Competition $\mathcal{E}$ Change, 19(4), 317-335.

Larsen, H. B. (2014). Governance, quality conventions, and product innovation in a value chain: The case of the Spanish salted fish market. Growth and Change, 45(3), 412-429.

Lund-Thomsen, P., Lindgreen, A., \& Vanhamme, J. (2016). Industrial clusters and corporate social responsibility in developing countries: What we know, what we do not know, and what we need to know. Journal of Business Ethics, 133(1), 5-8.

Lund-Thomsen, P., \& Nadvi, K. (2010). Global value chains, local collective action and corporate social responsibility: A review of empirical evidence. Business Strategy and the Environment, 19(1), 1-13.

Lund-Thomsen, P., \& Lindgreen, A. (2014). Corporate social responsibility in global value chains: Where are we now and where are we going? Journal of Business Ethics, 123, 11-22.

Lund-Thomsen, P. (2013). Labor agency in the football manufacturing industry of Sialkot, Pakistan. Geoforum, 44, 71-81.

Marimon-Viadiu, F., Casadesus-Fa, M., \& Heras-Saizarbitoria, I. (2006). ISO 9000 and ISO 14000 Standards: An international diffusion model. International Journal of Operations $\mathcal{E}$ Production Management, 26(2), 141-165.

Martin, D., \& Schouten, D. J. (2015). Sustainable marketing. Noida: Pearson.

Merriam, S. B. (1988). Case study research in education: A qualitative approach. San Francisco, CA: Jossey-Bass.

Merriam, S. B. (1998). Qualitative research and case study applications in education. San Francisco, CA: Jossey-Bass. 
Merriam, S. B. (2002). Qualitative research in practice: Examples for discussion and analysis. San Francisco, CA: Jossey-Bass.

Messner, D. (2002). World economic triangle: Global governance patterns and options for regions. IDS Working Paper. Brighton, UK: Institute of Development Studies.

Milberg, W., \& Winkler, D. (2010). Economic and social upgrading in global production networks: Problems of theory and measurement. Capturing the gains 2010. Working Paper. The University of Manchester. Manchester, UK.

Milberg, W., \& Winkler, D. (2011). Economic and social upgrading in global production networks: Problems of theory and measurement. International Labour Review, 150(3-4), 341-365.

Morrison, A., Pietrobelli, C., \& Rabellotti, R. (2008). Global value chains and technological capabilities: A framework to study learning and innovation in developing countries. Oxford Development Studies, 36(1), 39-58.

Nadvi, K. (2008). Global standards, global governance and the organization of global value chains. Journal of Economic Geography, 8(3), 323-343.

Nidumolu, R., Prahalad, C. K., \& Rangaswami, M. R. (2009). Why sustainability is now the key driver of innovation. Harvard Business Review, 87(9), 56-64.

O'Rourke, D. (2003). Outsourcing regulation: Analyzing nongovernmental systems of labor standards and monitoring. Policy Studies Journal, 31(1), 1-29.

Pakistan Today. (2014, May 26). 42 million soccer balls exported from Sialkot ahead of FIFA World Cup. Pakistan Today. Retrieved from http://www.pakistantoday.com.pk/2014/05/26/sports/42million-soccer-balls-exported-from-sialkot-for-fifa-world-cup/

Palpacuer, F., Gibbon, P., \& Thomsen, L. (2005). New challenges for developing country suppliers in global clothing chains: A comparative European perspective. World Development, 33(3), 409-430.

Patton, M. Q. (1990). Qualitative evaluation and research methods ( $1^{\text {st }}$ ed.). London, UK:Sage.

Pauwels, P., \& Matthyssens, P. (2004). The architecture of multiple case study research in international business. In R. M. Piekkari \& C. Welch (Eds.), Handbook of qualitative research methods for international business. Northampton, MA: Edward Elgar

Pickles, J. (2010). Capturing the gains in apparel global production networks: A scoping study. Retrieved November 27, 2011, from http://www.capturingthegains.org/membersarea/

Ponte, S., Gibbon, P. (2005). Quality standards, conventions and the governance of global value chains. Economy $\mathcal{G}$ Society, 34(1), 1-31.

Ponte, S., Gibbon, P., Vestergaard, J. (2011). Governing through standards: An introduction. In S. Ponte, P. Gibbon \& J. Vestergaard (Eds.), Governing through standards: Origins, drivers and limitations. New York: Palgrave Macmillan. 
Poulsen, R. T., Ponte, S., \& Lister, J. (2016). Buyer-driven greening? Cargo-owners and environmental upgrading in maritime shipping. Geoforum, 68, 57-68.

Ramirez, P., \& Rainbird, H. (2010). Making the connections: Bringing skill formation into global value chain analysis. Work Employment and Society, 24(4), 699-710.

Roger, K., \& Peterson, R. A. (2011). Strategic marketing problems: Cases and comments (12 ${ }^{\text {th }}$ ed.). Dorling Kindersley: India.

Saliola, F., \& Zanfei, A. (2009). Multinational firms, global value chains and the organization of knowledge transfer. Research Policy, 38(2), 369-381.

Siegmann, K. A. (2008). Soccer ball production for Nike in Pakistan. Economic and Political Weekly, 57-64.

Stigzelius, I., \& Mark-Herbert, C. (2009). Tailoring corporate responsibility to suppliers: Managing SA8000 in Indian garment manufacturing. Scandinavian Journal of Management, 25(1), 46-56.

Stake, R. E. (1995). The art of case study research. Thousand Oaks, CA: Sage

Stake, R. E. (2000). Case studies. In N. K. Denzin \& Y. S. Lincoln (Eds.), Handbook of qualitative research. London, UK: Sage.

Stake, R. E. (2003). Case studies. In N. K. Denzin \& Y. S. Lincoln (Eds.), Strategies in qualitative inquiry ( $2^{\text {nd }}$ ed.). Thousand Oaks, CA: Sage

State Bank of Pakistan. (2013). Prudential Regulations for Small \& Medium Enterprise infrastructure. Karachi: Housing \& SME Finance Department, Karachi.

Strauss, A. L., \& Corbin, J. (1990). Basics of qualitative research: Grounded theory procedures and techniques. Newbury Park, CA: Sage.

Sturgeon, T. J. (2009). From global commodity chains to global value chains: Interdisciplinary theory building in an age of globalization. In J. Bair (Ed.), Frontiers of commodity chain research. Stanford, CA: Stanford University Press.

Subic, A., Mouritz, A., \& Troynikov, O. (2009). Sustainable design and environmental impact of materials in sports products. Sports Technology, 2(3-4), 67-79.

The Green Buiding Information Gate. (2014). Retrieved on August 19, 2014, from http://www.gbig. org/search/site?q=Sri+Lankaandtype=buildings

United Nations Industrial Development Organization (UNIDO). (2007). Compliance Issues Affecting Enterprise Clusters in Punjab Province of Pakistan. Islamabad: UNIDO.

Van Maanen, J. (1979). Qualitative methodology. Newbury Park, CA: Sage.

Wong, C. Y., \& Johansen, J. (2008). A framework of manufacturer-retailer coordination process: Three case studies. International Journal of Retail E Distribution Management, 36(5), 387-408. 
Xue, H., \& Chan, A. (2013). The global value chain: value for whom? The soccer ball industry in China and Pakistan. Critical Asian Studies, 45(1), 55-77. 